\title{
Discriminatory Language in Pramoedya Ananta Toer's Works
}

\author{
Nunun Tri Widarwati ${ }^{1}$, Mangatur Nababan ${ }^{2}$, Riyadi Santoso ${ }^{3}$, Sri Samiati Tarjana ${ }^{4}$ \\ $\left\{{ }^{1}\right.$ nununtriwidarwati@gmail.com, ${ }^{2}$ Amantaradja@yahoo.com, ${ }^{3}$ riyadisantosa@staff.uns.ac.id, \\ 로sisamiati@staff.uns.ac.id\} \\ Universitas Sebelas Maret, Indonesia
}

\begin{abstract}
This study is about discriminatory language in Pramoedya Ananta Toer's works 'Anak Semua Bangsa', 'Rumah Kaca', and 'Jejak Langkah'. Precisely, it examines forms of discrimination realized through discriminatory expressions. Data for the study were obtained with document analysis and FGD (Focus Group Discussion). Results of data analysis show that the unequal use of language in this study relates to social class and gender. Social class discrimination takes the forms of subordination, stereotyping, marginalization, and violence. In addition to workload, gender discrimination also takes similar forms of discrimination. It is of great importance to note, however, subordination forms dominantly appear within the two variables.
\end{abstract}

KeyWords: discriminatory expressions, social class, gender, Pramoedya Ananta Toer

\section{INTRODUCTION}

God creates humans equally but man treats each other differently and this phenomenon arises from differences in how people behave economically, politically, socially, culturally and ideologically. To a large extent, all of their economic, political, social, cultural and ideological behaviors are expressed through verbal and non-verbal expressions.

The present paper reports a small part of a large study which attempts to examine how discriminatory expressions are translated and how translation techniques utilized by the translator affect the translation quality. As a preliminary stage, this study merely identifies linguistic evidences of social and gender discriminations and then looks closely at the forms of social and gender discriminations. In order to suggest a strong claim about findings of this 
preliminary study, it is necessary to describe how scholars define discrimination in general and how they view discriminatory expressions.

Discrimination refers to human attitudes towards others and it appears as a result of wrong perception of differences within community members. The differences naturally occur; in some cases, however, they are socially constructed. According to Theodorson \& Theodorson [1] discrimination constitutes an unequal treatment on someone or community groups on the basis of particular attributes such as race, religion and social class. The emerge of this unequal treatment results from wrong perception about other people or other community groups having different background. With similar vein, Sears et al [2] defines discrimination as an attitude of accepting or rejecting other people or other community groups due to labels attributed to them.

Discrimination may relate to social class and gender. The social class-related discrimination is divided into some subcategories; these include 1) racial and religion discrimination, 2) gender discrimination, 3) disabaility discrimination, 4) discrimination toward those suffering from HIV/AIDS, and 5) social class discrimination [3] (Fulthoni, 2009: 5). Meanwhile, gender discrimination describes the situation in which people are treated differently simply because they are male or female, rather than on the basis of their individual skills or capabilities.

Social discrimination is manifested in some forms. Handayani [4] states that social discrimination can be in the forms of marginalization, subordination, stereotyping, physical and mental domestic violences, and workload. Gender discrimination also takes similar forms which are generally realized through sexist attitude and language.

The present study belongs to a qualitative and descriptive research. Data for the study are verbal expressions which were selected purposively from Pramoedya Ananta Toer's novels Anak Semua Bangsa' [5], 'Rumah Kaca [6]', and 'Jejak Langkah'[7] through document analysis and validated in Focus Group Discussion (FGD). The data were analysed with Spradley [8] technique of data analysis consisting of domain analysis, taxonomic analysis, componential analysis and the analysis of cultural theme.

\section{RESEARCH FINDINGS AND DISCUSSION}

\section{a. Research Findings}

As has been stated previously, discrimination examined in this study relates to social and gender discriminations which were realized through verbal expressions. Through document analysis, 302 data were identified. Of this figure, 227 data are expressions indicating social class discrimination and the other 75 data belong to gender discriminations. As summarized in Table 3.1, social class discriminations consist of four subcategories: subordination, stereotyping, marginalization and physical and mental domestic violences.

Table 1. Forms of Social Discrimination

\begin{tabular}{clcc}
\hline No & Forms of Discriminatation & Subtotal & Percentage \\
\hline 1 & Subordination & 146 & 64.18 \\
\hline 2 & Stereotyping & 59 & 25.99 \\
\hline 3 & Marginalization & 16 & 7.05
\end{tabular}




\begin{tabular}{clcc}
4 & Domestic Violences & 6 & 2.64 \\
\hline Total & 227 & 100
\end{tabular}

Table 2. Forms of Gender Discrimination

\begin{tabular}{clcc}
\hline No & Forms of Discrimination & Subtotal & Percentage \\
\hline 1 & Subordination & 42 & 56 \\
\hline 2 & Stereotyping & 25 & 33.33 \\
\hline 3 & Marginalization & 3 & 4 \\
\hline 4 & Workload & 3 & 4 \\
\hline 5 & Domestic Violences & 2 & 2.66 \\
\hline & Total & 75 & 100
\end{tabular}

Table 3.1 shows that social discrimination found in this study suggests four forms of discrimination. Subordination and stereotyping appear to be the most frequently practices. Other two forms of discrimination, that is marginalization and domestic violences, are also identified although they are small in number. In addition to workload, gender discrimination, as summarized in Table 3.2 also takes similar forms of discrimination. It is clear that subordination and stereotyping dominate other forms of gender inequality. The following data exemplify forms of discriminatory expressions identified in Pramoedya Ananta Toer's works 'Anak Semua Bangsa', 'Rumah Kaca', and 'Jejak Langkah.

\begin{tabular}{|c|c|c|}
\hline Subordination & b. & $\begin{array}{l}\text { "Apa kau kira hanya Belanda dan turunannya saja yang } \\
\text { patut jadi istrimu?" } \\
\text { "Seluruh dunia kekuasaan memuji-muji yang kolonial. Yang } \\
\text { tidak kolonial dianggap tidak punya hak hidup, termasuk } \\
\text { mamamu ini." } \\
\text { "Barulah berhenti, sebab babu adalah manusia terakhir } \\
\text { dalam kehidupan." }\end{array}$ \\
\hline Stereotyping & b. & $\begin{array}{l}\text { "Hanya anak dusun busuk berkopor lebih busuk semacam } \\
\text { ini." } \\
\text { Bunda bilang perempuan semacam itu pada dasarnya } \\
\text { pelacur. }\end{array}$ \\
\hline Marginalization & b. & $\begin{array}{l}\text { Syarikat ini takkan bakal mendapatkan anggota dari } \\
\text { kalangan serendah-rendahnya, karena nama priyayi itu. } \\
\text { Mengapa diantara anak-anaknya sendiri, yang karena } \\
\text { kebetulan saja jadi lelaki, berkeberatan setengah mati kalau } \\
\text { wanita tapil ke depan umum? }\end{array}$ \\
\hline $\begin{array}{l}\text { Domestic (physical or } \\
\text { mental) violence }\end{array}$ & b. & $\begin{array}{l}\text { Perlakuan sewenang-wenang dalam perusahaan keretapi, } \\
\text { perkebunan, kantor-kantor Gubernur, ... } \\
\text {...wanita-wanita harus didiamkan dengan menaikkannya ke } \\
\text { ranjang pengantin. }\end{array}$ \\
\hline Workload & a. & $\begin{array}{l}\text {...wanita-wanita harus didiamkan dengan menaikkannya ke } \\
\text { ranjang pengantin. }\end{array}$ \\
\hline
\end{tabular}


b. "Perempuan dipukuli lelaki, polisi sampai meraung seperti itu."

\section{b. Discussion}

The findings of this study clearly shows how Pramoedya Ananta Toer, the leading Indonesian prose writer, illustrates practices of social and gender discrimination in his works. Though fictional in nature, the phenomenon closely relates to emerging political, social and cultural conditions during which the works were created.

It is interesting to note that forms of discrimination vary but subordination and stereotyping appear to be the most dominant ones. The occurrence of social and gender discrimination is basically understood as the manifestation of the social stratum and gender roles in Javanese community. The Javanese proverb "suwargo nunut neroko katut", for example, represents how Javanese people see women as subordinate to men. Moreover, the existence of Javanese speech level inevitably contributes significantly to the emergence of such discriminations.

Whatever the forms of discrimination found in this study, some interesting questions remain challenging for further research: 1) how did the translator treat such kinds of discriminatory expressions?, 2) What kinds of attempt did he or she make to maintain the uniqness of the original culture or to conform to the target culture and norm for acceptability purposes?, and 3) How did the impact of translation techniques on the translation quality.

\section{CONCLUSION}

Based on the results of data analysis, this study concludes the followings. First, discrimination may relate to social and gender ones. The forms of discrimination vary and include subordination, stereotyping, marginalization, physical and mental domestic violences, and workload. Though fictional in nature, the discriminatory expressions identified in Pramoedya Ananta Toer's works illustrate unequal treatment due to social stratum and gender differences in Javanese community.

\section{REFERENCES}

[1] Theodorson, George A, and Achilles G. Theodorson. 1979. A Modern Dictionary of Sociology. New York,

Hagerstown, San Francisco, London: Barnes \& Noble Books.

[2] Sears, D. O., and J. Citrin. 1985. Tax Revolt: Something for Nothing in California. Enlarged edition.

Cambridge, MA: Harvard University Press.

[3] Handayani, Trisakti. 2006. Konsep dan Teknik Penelitian Gender; UMM Press Malang

[4] Fulthoni 2009. Memahami Diskriminasi: Buku Saku Kebebasan Beragama. Jakarta: The Indonesian Legal Resource Center (ILRC), pp. 5 
[5] Spradley, J.P. (1997). Metode Etnografi. (Diterjemahkan oleh Misbah Yulfa Elisabeth). Yogyakarta: PT. Tiara Wacana Yogya.

[6] Toer, Pramoedya Ananta. 2006. Anak Semua Bangsa. Jakarta: Gramedia Pustaka Utama

[7] Toer, Pramoedya Ananta. 2007. Jejak Langkah. Jakarta: Lentera Dipantera

[8] Toer, Pramoedya Ananta. 2009. Rumah Kaca. Jakarta: Gramedia Pustaka Utama 